\title{
Currarino syndrome presenting as a cerebrospinal fluid leak from the dermal sinus tract: case report
}

\author{
Robert B. Kim, MD, ${ }^{1}$ Riann Robbins, MD, ${ }^{2}$ Michael D. Rollins, MD, ${ }^{2}$ and \\ Douglas L. Brockmeyer, MD'
}

Divisions of ${ }^{1}$ Pediatric Neurosurgery and 2 Pediatric Surgery, Primary Children's Hospital, University of Utah, Salt Lake City, Utah

Currarino syndrome is an autosomal dominant condition with variable expressivity and penetrance that is associated with several classic features: sacral dysgenesis, presacral mass, and/or anorectal anomalies. The authors present a unique case in which the patient's initial presentation was a CSF leak from a sinus tract. The sinus tract was identified and disconnected from the thecal sac, obliterating the anterior sacral meningocele. This case represents a unique scenario in which Currarino syndrome manifested as a CSF leak from a dermal sinus tract.

https://thejns.org/doi/abs/10.3171/2020.1.PEDS19692

KEYWORDS Currarino syndrome; cerebrospinal fluid leak; dermal sinus tract; spine

$\mathrm{I}$ N 1981, Currarino et al. ${ }^{6}$ described a series of infants who presented with a sacral defect, presacral mass, and anorectal anomalies, which became known as the Currarino triad. Since then, over 300 cases have been reported in the literature, indicating that the Currarino triad represents a spectrum disorder with highly variable morphological and clinical characteristics. Thus, the term Currarino "syndrome" has replaced "triad." Genetic analysis has shown that the syndrome follows an autosomal dominant pattern, with both sporadic and familial cases associated with underlying mutation in the MNX1 gene (previously $H L X B 9$ ) located on chromosome 7q36.5,11,19,20

The sacral defect may resemble a scimitar in its appearance. The presacral mass may consist of dysraphic lesions such as dermoid, epidermoid, anterior meningocele, or intradural lipoma, which may be associated with tethered cord., ${ }^{9,14}$ In some cases, it may present with a benign or malignant teratoma. ${ }^{3,13}$ The anorectal anomalies have been described as imperforate anus, rectoperineal fistula, rectourethral fistula, rectovestibular fistula, or anorectal stenosis. ${ }^{8}$

Because of its significant morphological variability and severity, Currarino syndrome can present with a wide range of symptoms, the most common of which are obstructive in nature because the enlarging presacral mass exerts local mass effect in the surrounding bowel, bladder, or both. In rare instances, rectothecal fistulas may develop, leading to meningitis or a presacral abscess. ${ }^{10,21}$ We present the case of a young girl who had known asymptomatic Currarino syndrome with presacral meningocele and who presented with a CSF leak from a dermal sinus tract located adjacent to the anus.

\section{Case Report}

History and Examination

The patient is a 10 -year-old girl who initially presented with symptoms of a tethered cord at age 5. During workup, she was found to have scimitar-appearing sacral dysgenesis and an anterior sacral meningocele. Genetic workup revealed she carried a 7q36 deletion. She underwent a laminectomy to release the fatty filum terminale and has been under surveillance for her asymptomatic anterior sacral meningocele. She presented with a 3-day history of headache and clear drainage from her rectum, which was concerning for a CSF leak. The bedside rectal examination was unremarkable. MRI demonstrated new wall thickening and enhancement of the wall of the known anterior sacral meningocele and a possible rectothecal fistulous tract (Fig. 1). She had mild leukocytosis, and her inflammatory markers were negative. Beta-2 transferrin was detected in the collected fluid. She was otherwise neurologically intact. 

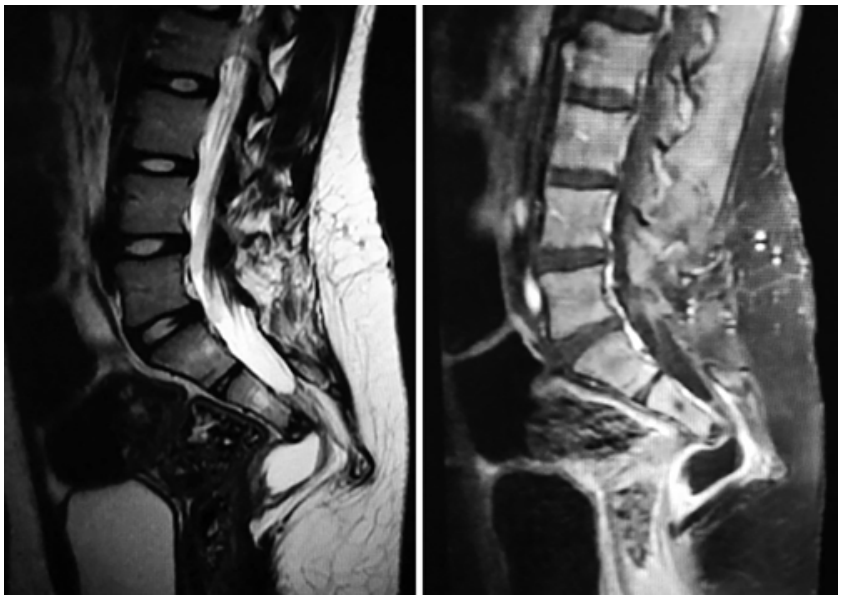

FIG. 1. MR images of lumbosacral spine. Left: Sagittal T2-weighted sequence showing a sacral defect at S3 with an anterior sacral meningocele herniating through the presacral space. Right: Sagittal T1-weighted postcontrast image demonstrating wall thickening and enhancement.

\section{Operation}

After review with the patient and family, the patient underwent sacral laminectomy and closure of the presumed fistulous connection between the anterior sacral meningocele and rectum. This was done with assistance from the pediatric surgery team. When the patient was placed in the prone jack-knife position to allow for a posterior sagittal approach, the opening of the sinus tract that was previously not visible on bedside examination was noted immediately superior to the anus (Figs. 2 and 3A). Using a posterior sagittal incision, the sinus tract was dissected circumferentially to the level of the anterior meningocele, while avoiding injury to the anus or rectum (Figs. 3B and 4C). Dissection was continued until the distal end of the spinal thecal sac was encountered. At this point, a right sacral hemilaminectomy and resection of coccyx were performed to expose the distal thecal sac and its connection to the anterior sacral meningocele, and the meningocele was entered (Fig. 4C). Within the inflamed wall of the meningocele, there was a neural element and a small piece of tissue containing hair that resembled dermoid elements. Neuromonitoring indicated that the neural element had S2-4 responses. The anterior meningocele sac was resected around this neural element while preserving it. Once we dissected up to the distal part of the sacral thecal sac, we closed the thecal sac primarily using 4-0 Nurolon sutures (Ethicon) (Fig. 3C). The levator muscle and posterior aspect of the anal sphincter complex were reapproximated in the midline.

\section{Postoperative Course}

There were no perioperative or postoperative complications. Four weeks postoperatively, the patient underwent MRI of the lumbosacral spine, which demonstrated a completely resected anterior sacral meningocele (Fig. 5). The final pathology for the presacral mass was a dermoid cyst. The patient was ambulating independently and remains continent of stool.

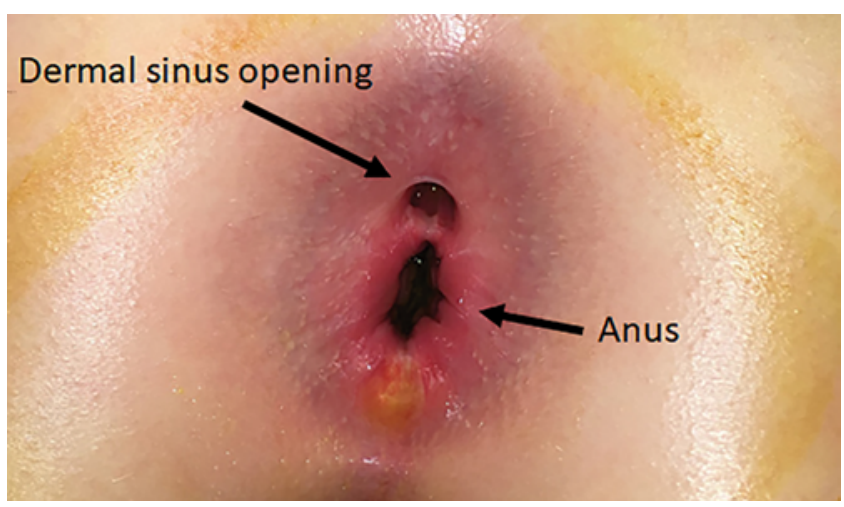

FIG. 2. Photograph showing the dermal sinus tract found superior to the anus. Figure is available in color online only.

\section{Discussion}

Currarino syndrome is a rare congenital disorder that presents with a highly variable constellation of symptoms due to its morphology and effects on surrounding structures. Here, we have reported a unique case in which the patient presented with a CSF leak from a sinus tract, leading to surgical intervention to close the fistulous connection between the anterior sacral meningocele and the sinus opening.

Since the initial description of the Currarino triad, numerous case reports have demonstrated the variable clinical phenotype of the syndrome., ${ }^{2,3,12,14-16,21}$ The majority of patients are asymptomatic, ${ }^{17}$ having only hemisacrum without an associated presacral mass or anorectal anomalies. Some patients may have a sacral anomaly associated with either an anorectal malformation or a presacral mass. ${ }^{9}$ In the most severe cases, the patients present with the classic triad of sacral dysgenesis, presacral mass, and anorectal anomaly with or without spinal cord tethering. ${ }^{4}$ These three variations were later classified as minimal, mild, and complete Currarino syndrome..$^{18,19}$ Intuitively, symptoms vary depending on the severity of the syndrome. The most common symptom is chronic constipation, which is seen more frequently in the pediatric population. ${ }^{10}$ In rare cases, obstipation and an inability to pass meconium may occur, which can lead to early diagnosis.? In asymptomatic individuals, the presacral mass may enlarge later in life, causing abdominal distention, ${ }^{12}$ constipation, and even a rectothecal fistula, causing local inflammation or meningitis. ${ }^{10}$

Any patient born with an anorectal malformation should be evaluated for a possible sacral or spinal cord anomaly. In our patient, the anus appeared normal during a bedside rectal examination. It was not until the patient was positioned under general anesthesia that the opening to the sinus tract was visible. Upon closer inspection, CSF was draining through the opening of the sinus, rather than the anus, making this case a unique addition to the constellation of existing symptoms. Patients with CSF leaks usually present with meningitis. It is estimated that about $13 \%$ of the patients with Currarino syndrome present with a CSF leak. Of these, about $16 \%$ of patients have an anal or rectal fistula. ${ }^{1,10}$ 


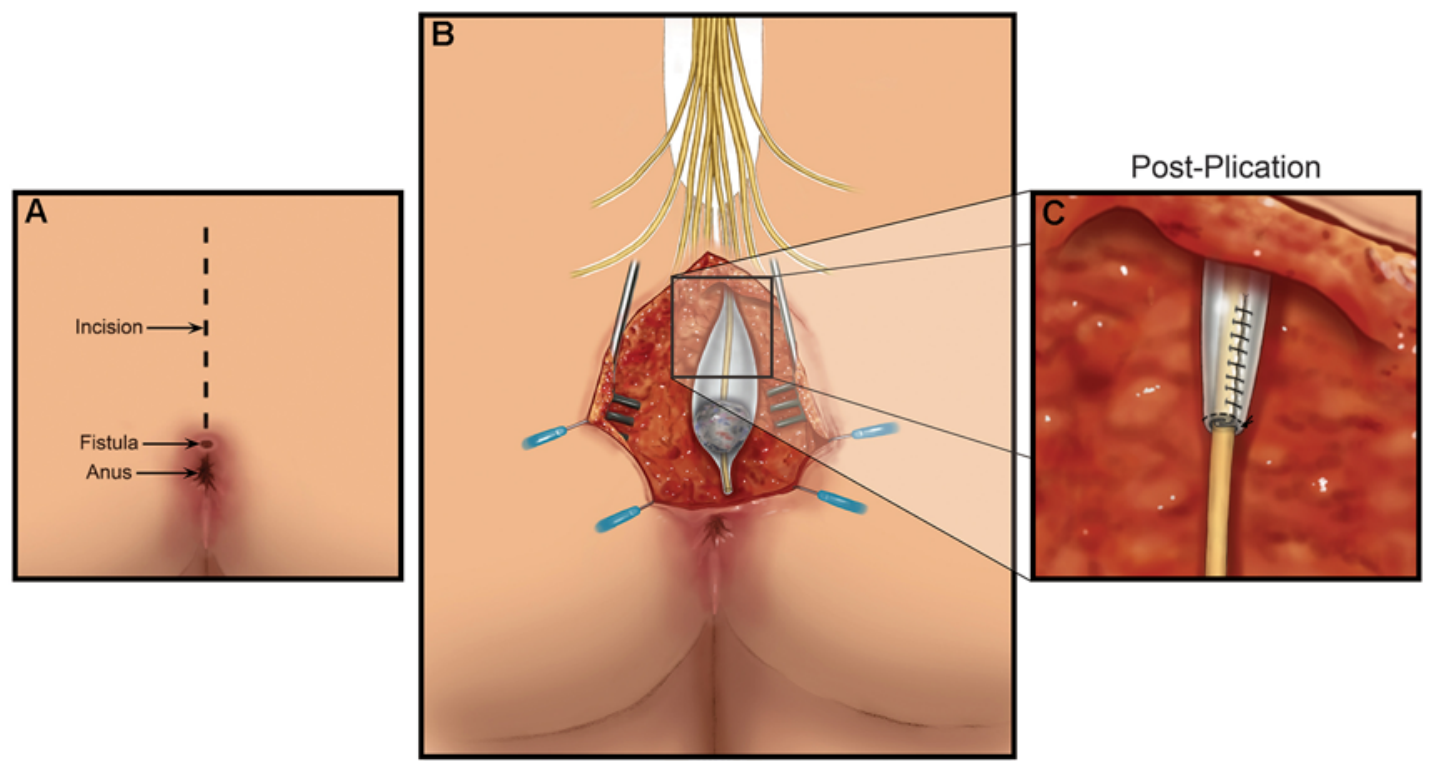

FIG. 3. Illustrations depicting surgical plan and anatomy. A: A dermal sinus tract was found superior to the anus. A linear midline incision was planned. B: The dermal sinus tract was isolated and circumferentially dissected. C: The dermoid element and inflamed sac were both resected. The superior part of the sac was plicated around the neural element. Copyright J. Williams Medical Art. Published with permission. Figure is available in color online only.

A presacral mass is often seen in patients with Currarino syndrome. ${ }^{17,22}$ Anterior sacral meningoceles and teratomas are commonly encountered; however, reports have indicated that dysraphic lesions, including enteric cysts, dermoid/epidermoid cysts, intradural lipomas, lipomyelomeningocele, leiomyosarcomas, hamartomas, and some combination, can also be found., $3,9,13,14$ Sometimes, the lesions may contain neural elements, which may or may not be functioning. Therefore, if resection is indicated, a meticulous dissection and neuromonitoring are required to preserve any encountered functioning neural elements. Our patient had a neural element that had S2-4 responses, as well as some dermoid element, which we resected while preserving the nerve root.

A growing awareness of the familial tendency of the syndrome has led to extensive genetic studies. Currarino syndrome is now considered a complex disorder with variable genetic penetrance and expressivity. It is inherited in an autosomal dominance pattern with underlying defects in the $M N X 1$ gene, which encodes the homeobox protein. ${ }^{4}$ Previously named $H L X B 9$, this gene is located on chromosome 7q36.5,11,19,20 Deletion of this gene can be found sporadically in about $30 \%$ of the affected individuals and a majority of the familial cases. ${ }^{4}$ It is speculated that mutation in the $M N X 1$ gene may be associated with aberrant interaction between the endoderm and notochord in the early embryologic process or during secondary neurulation, which result in sacral dysgenesis. Recently, Costanzo et al. ${ }^{4}$ studied the effects of the $M N X 1$ gene mutation on the severity of Currarino syndrome. They demonstrated
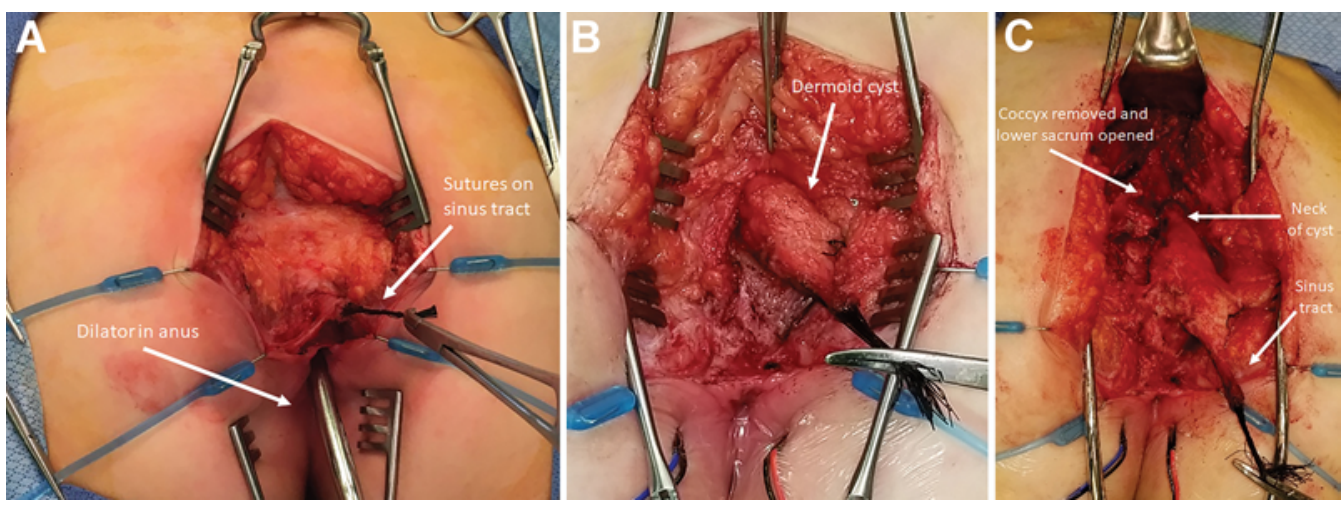

FIG. 4. Photographs showing further dissection of the dermal sinus tract revealing a pouch-like structure that contained neural and dermoid elements. A: Sutures placed around the dermal sinus tract opening and dissection started. B: Further dissection reveals the dermoid cyst. C: After removing the coccyx and hemisacrum, the neck of the cyst is encountered. Figure is available in color online only. 


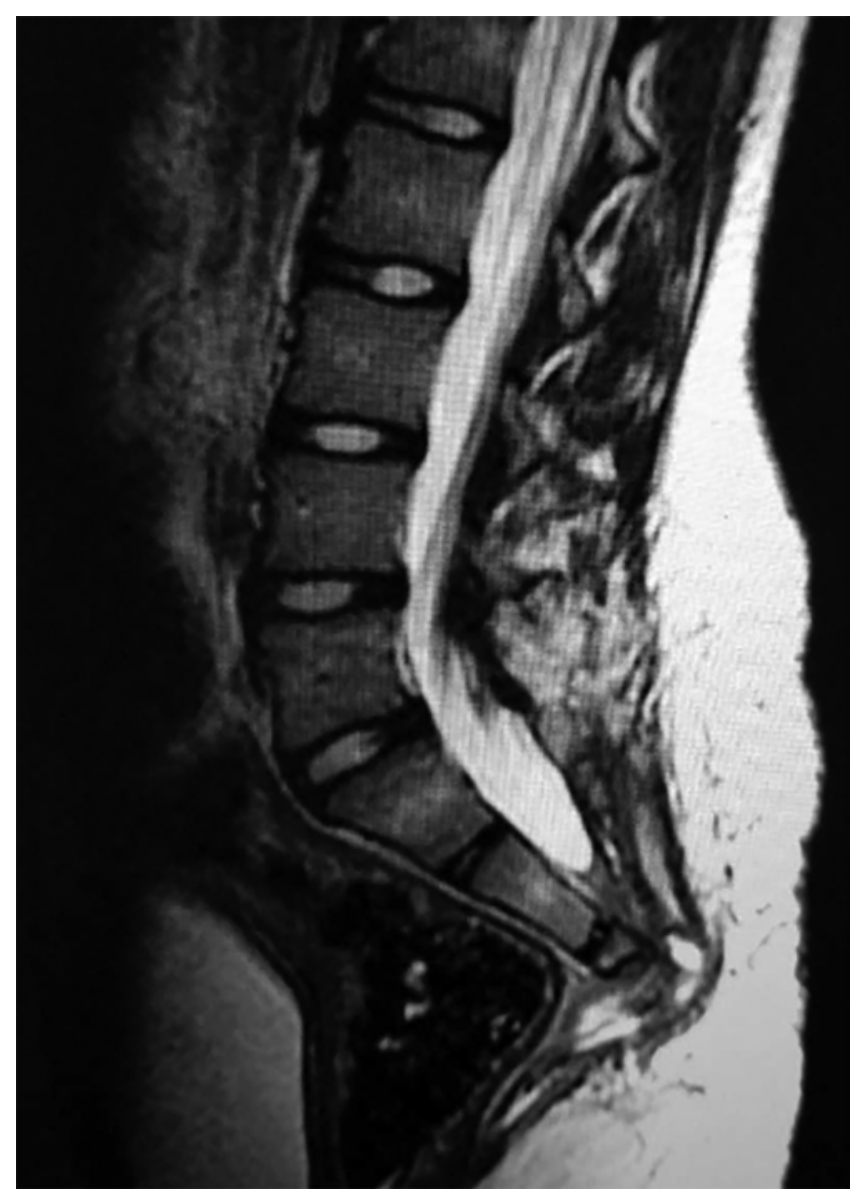

FIG. 5. Postoperative MR image obtained 6 weeks after surgery showing complete obliteration of the anterior sacral meningocele.

that MNX1 mutation was correlated with greater severity of Currarino subtype (i.e., complete vs mild and minimal).

Surgical management of patients with Currarino syndrome must be developed on an individual basis. Asymptomatic Currarino syndrome may be monitored conservatively. Patients with symptomatic Currarino syndrome may be surgical candidates, with the goal of reducing mass effect by total or subtotal excision or simply by disconnecting the fistulous site to minimize perioperative complications. Various surgical approaches have been suggested for resection of the anterior sacral mass. Most commonly, a posterior approach will be used, which often involves partial or complete sacral laminectomy to visualize the sacral mass lesion. An anterior approach can also be used in some cases for ventral access. A multidisciplinary one-step anterior-posterior combined approach has also been described. ${ }^{3}$

\section{Conclusions}

Because of the extreme rarity of the condition, patients with Currarino syndrome may experience delay in diagnosis, which can lead to increased complications in this cohort. Patients with Currarino syndrome present with a wide array of presentations and severity. We describe a new presentation of clear drainage from a sinus tract asso- ciated with Currarino syndrome. Any drainage associated with anorectal anomalies must be investigated further using advanced imaging.

\section{Acknowledgments}

We thank Kristin Kraus, MSc, for editorial support.

\section{References}

1. Blond MH, Borderon JC, Despert F, Laugier J, Maheut J, Robert M, et al: Anterior sacral meningocele associated with meningitis. Pediatr Infect Dis J 10:783-784, 1991

2. Caro-Domínguez P, Bass J, Hurteau-Miller J: Currarino syndrome in a fetus, infant, child, and adolescent: spectrum of clinical presentations and imaging findings. Can Assoc Radiol J 68:90-95, 2017

3. Chakhalian D, Gunasekaran A, Gandhi G, Bradley L, Mizell J, Kazemi N: Multidisciplinary surgical treatment of presacral meningocele and teratoma in an adult with Currarino triad. Surg Neurol Int 8:77, 2017

4. Costanzo S, Spaccini L, Pio L, Mattioli G, Virgone C, Dall'Igna P, et al: Currarino syndrome: does the presence of a genetic anomaly correlate with a more severe phenotype? A multicentre study. J Pediatr Surg 52:1591-1596, 2017

5. Crétolle C, Pelet A, Sanlaville D, Zérah M, Amiel J, Jaubert F, et al: Spectrum of HLXB9 gene mutations in Currarino syndrome and genotype-phenotype correlation. Hum Mutat 29:903-910, 2008

6. Currarino G, Coln D, Votteler T: Triad of anorectal, sacral, and presacral anomalies. AJR Am J Roentgenol 137:395398, 1981

7. de Lagausie P, Munck A, Hertz Pannier L, Aigrain Y, Dupont A, Boureau M: [Currarino syndrome: an association not to be overlooked.] Arch Fr Pediatr 48:631-634, 1991 (French)

8. Dias MS, Azizkhan RG: A novel embryogenetic mechanism for Currarino's triad: inadequate dorsoventral separation of the caudal eminence from hindgut endoderm. Pediatr Neurosurg 28:223-229, 1998

9. Emans PJ, van Aalst J, van Heurn EL, Marcelis C, Kootstra G, Beets-Tan RG, et al: The Currarino triad: neurosurgical considerations. Neurosurgery 58:924-929, 2006

10. Haga Y, Cho H, Shinoda S, Masuzawa T: Recurrent meningitis associated with complete Currarino triad in an adultcase report. Neurol Med Chir (Tokyo) 43:505-508, 2003

11. Hagan DM, Ross AJ, Strachan T, Lynch SA, Ruiz-Perez V, Wang YM, et al: Mutation analysis and embryonic expression of the HLXB9 Currarino syndrome gene. Am J Hum Genet 66:1504-1515, 2000

12. Hage P, Kseib C, Adem C, Chouairy CJ, Matta R: Atypical presentation of currarino syndrome: a case report. Int J Surg Case Rep 57:102-105, 2019

13. Köchling J, Karbasiyan M, Reis A: Spectrum of mutations and genotype-phenotype analysis in Currarino syndrome. Eur J Hum Genet 9:599-605, 2001

14. Kole MJ, Fridley JS, Jea A, Bollo RJ: Currarino syndrome and spinal dysraphism. J Neurosurg Pediatr 13:685-689, 2014

15. Kumar B, Sinha AK, Kumar P, Kumar A: Currarino syndrome: rare clinical variants. J Indian Assoc Pediatr Surg 21:187-189, 2016

16. Kurosaki M, Kamitani H, Anno Y, Watanabe T, Hori T, Yamasaki T: Complete familial Currarino triad. Report of three cases in one family. J Neurosurg 94 (1 Suppl):158-161, 2001

17. Lynch SA, Wang Y, Strachan T, Burn J, Lindsay S: Autosomal dominant sacral agenesis: Currarino syndrome. J Med Genet 37:561-566, 2000

18. Martucciello G, Torre M, Belloni E, Lerone M, Pini Prato A, 
Cama A, et al: Currarino syndrome: proposal of a diagnostic and therapeutic protocol. J Pediatr Surg 39:1305-1311, 2004

19. Merello E, De Marco P, Ravegnani M, Riccipetitoni G, Cama A, Capra V: Novel MNX1 mutations and clinical analysis of familial and sporadic Currarino cases. Eur J Med Genet 56:648-654, 2013

20. Ross AJ, Ruiz-Perez V, Wang Y, Hagan DM, Scherer S, Lynch SA, et al: A homeobox gene, HLXB9, is the major locus for dominantly inherited sacral agenesis. Nat Genet 20:358-361, 1998

21. Shoji M, Nojima N, Yoshikawa A, Fukushima W, Kadoya N, Hirosawa H, et al: Currarino syndrome in an adult presenting with a presacral abscess: a case report. J Med Case Reports 8:77, 2014

22. Urioste M, Garcia-Andrade MDC, Valle L, Robledo M, González-Palacios F, Méndez R, et al: Malignant degeneration of presacral teratoma in the Currarino anomaly. Am J Med Genet A 128A:299-304, 2004

\section{Disclosures}

The authors report no conflict of interest concerning the materials or methods used in this study or the findings specified in this paper.

\section{Author Contributions}

Conception and design: Brockmeyer, Rollins. Acquisition of data: Kim, Robbins. Drafting the article: all authors. Critically revising the article: all authors. Reviewed submitted version of manuscript: Brockmeyer, Kim. Approved the final version of the manuscript on behalf of all authors: Brockmeyer.

\section{Correspondence}

Douglas L. Brockmeyer: Primary Children's Hospital, University of Utah, Salt Lake City, UT. neuropub@hsc.utah.edu. 